\title{
Re-membering the Self Psychoanalytic Theory and Subjectivity in Adolescent Fiction
}

\author{
Cathy Sly
}

\begin{abstract}
'Who are you?' said the Caterpillar:
This was not an encouraging opening for the conversation. Alice replied, rather shyly, I - I hardlyknow, sir; justat present-at least I know who I was when I got up this morning, but I think I must have been changed several times since then.
\end{abstract}

'What do you mean by that?' said the Caterpillar sternly. 'Explain yourself!'

'I can't explain myself, I am afraid, sir, 'said Alice, 'because I'm not myself, you see.'

'I don't see, 'said the Caterpillar.

Lewis Carroll, Alice in Wonderland

$\mathrm{L}$

ewis Carroll's enigmatic dialogue between Alice and the hookah-smoking Caterpillar in Alice in Wonderland (1865) anticipates a search for self that has become a recurrent theme in contemporary young adult literature. Adolescence in Western society is often seen as a time of crisis in which the identity that existed in the realm of the child needs to be reconstructed in order to cope with the expectations and demands of the adult world. Writers of adolescent fiction have tapped into this concern and so 'ideas about and representations of subjectivity underpin adolescent fiction.' (McCallum 1999, p.3).

Although the construction of subjectivity in young adult fiction has tended to be based predominantly on the humanistic model, more recently contemporary young adult fiction has been geared towards a more problematized notion of subjectivity, symptomatic of and informed by post-structural thought. It is, according to Nick Mansfield, the intensification of the self as a key site of human experience and its increasing sense of internal fragmentation and chaos - that the twentieth century's theorists of subjectivity have tried to deal with. '(Mansfield 2000, p.2).

The notion of the 'subject' in contemporary discourses can be decidedly complex. While it is often used synonymously with 'self', 'identity', 'persona', or 'individual', to theorists like Paul Smith the 'subject' is a far more complicated entity. He argues that in psychoanalytical discourse it is inextricably linked to the unconscious and may be 'perceived in dreams, slips and jokes.' (Smith 1988. p.71). This discussion mobilises psychoanalytic theories in the analysis of subjectivity in young adult fic- tion to generate a greater understanding and appreciation both of the individual works of imagination and of the usefulness of psychoanalytic principles in exploring the meanings of these texts.

Contemporary young adult fiction contains many examples of alienated, fragmented protagonists who seek to remember and reconcile a selfhood they believed they once had. Since the publication of J.D. Salinger's The Catcher in the Rye (1951) there has been a steady succession of angst-ridden, adolescent anti-heroes. Robert Cormier is renowned for his grim, realistic novels in which the teenage protagonists often move further and further into despair. The Chocolate War (1974) and I am the Cheese (1977) present young adults who are desperately alienated and have little hope of any improvement in their circumstances. Australian writers like John Marsden in Letters from the Inside (1992) and Dear Miffy (1997) and Sonya Hartnett in Sleeping Dogs (1995) also present seriously estranged adolescent protagonists whose notions of self are extremely fragmented. Other authors like Caroline McDonald and Gary Crew explore the idea of the doppelgänger in narratives such as Speaking to Miranda (1990) and Strange Objects (1993). This notion of a divided self offers another intriguing means of exploration into the notion of subjectivity. The three contemporary novels selected for close analysis in this paper are I Am NOT Esther by Fleur Beale (1998); Incognito by Claire Carmichael (2000); and Across the Nightingale Floor by Lian Hearn (2002). These novels span a range of genres from realism, through science fiction and historical fantasy.

The analysis of the representation of subjectivity in this selection of adolescent fiction will be informed by psychoanalytic theories, especially through the writings of Jacques Lacan and Julia Kristeva. Both Lacan and Kristeva recognise changes in the understanding of subjectivity that have 'recast the notion of the self ... (whereby) attention has shifted from the intrapsychic world of object representations to the relationship between self and others.' (Elliott 1994, p. 18). This perception of subjectivity sees its formation occurring 'in dialogue with social discourses, practices and ideologies.' (McCallum 1999, p.4). Significant aspects of Lacan's work including his formulation of the 'mirror-stage', the 'Name-of-the-Father' and 'the 
Gaze' along with Kristeva's notion of Abjection, will underpin interpretations of the adolescent novels selected for analysis in this paper

While I Am NOT Esther, Incognito and Across the Nightingale Floor represent very different fictional genres, they display interesting links in relation to notions of subjectivity. Each text exposes an adolescent protagonist who experiences displacement from one realm of experience to another. Identities which existed in earlier social contexts are destroyed, leaving them bereft of any understanding of self. New selves are reconstructed in discourse with other 'social and cultural forces, ideologies and other selves. (McCallum 1999. p.5). Alternatively, as Karen Coats suggests, 'The adolescent moves back in developmental time to the mirror stage, to a time when questions of alienation and identification. separation and the establishment of boundaries between the me and not-me, need to be resettled.' (Coats 2000, p. 293). Citing a number of theorists concerned with identity development, Jane Kroger argues that 'the internal balancing and rebalancing of boundaries between self and other produce more differentiated subject experiences at different life stages. Adolescence encompasses one phase of heightened activity for most in this intrapsychic juggling act.' (Kroger 1996, pp. 8-9).

In each of the selected texts the main character is initially introduced as an integrated self in a stable situation, but rapidly these circumstances alter, leading to loss, disintegration and alienation. An enforced identity change is the basis of extreme anxiety for Kirby Greenland in I Am NOT Esther. Identity loss as a result of being obliterated from the central data base is the cause of alienation for Karr Robinson in Incognito, and the destruction of his village, a change of name and movement to a different socio-cultural context accents the feeling of loss for young Tomasu in Across the Nightingale Floor. Such psychic turmoil in any context is likely to elicit the empathy of intended adolescent readers. They can become travellers vicariously experiencing the psychic journey the protagonist has to take in order to re-member her/his disintegrated self.

In her comprehensive analysis on Ideologies of Identity in Adolescent Fiction, Robyn McCallum presents a detailed argument on solipsism in children's fiction. She claims this solipsism manifests itself in alienation that can be observed as 'powerlessness, meaninglessness, normlessness, social isolation, self-estrangement and cultural estrangement.' (McCallum 1999, p.99). McCallum explores three specific narrative strategies that are often employed in conveying the alienated subject. The first strategy seeks to 'displace a character out of his/her familiar surroundings' in order to destabilise any sense of identity (McCallum 1999, p.100). Secondly, this displacement allows the means of observing 'linguistic and sociocultural influences on cognition and formation of subjectivity'; and finally, McCallum argues that transgressive modes of behaviour "can construct interpretative positions from which to examine and interrogate the limitations that the dominant cultural and social discourses of a given society or culture place on experience, action and subjectivity.' (McCallum 1999. pp.100-101). Such narrative strategies provide some additional points of reference in the analysis of subjectivity in young adult fiction.

In the psychological thriller I am NOT Esther by New Zealand author Fleur Beale, the fourteen-year-old protagonist Kirby Greenland is stripped of her identity when she is forced to live with her uncle Caleb Pilgrim and his family, in a fundamentalist religious sect known as The Children of the Faith. Initially Kirby is introduced as a responsible young adolescent who is devoted to dealing with domestic duties such as budgeting, bill paying, and shopping for herself and her somewhat dysfunctional "dizzy flake of a mother' (Beale 1998, p.8) whom she dearly loves. However, circumstances change rapidly when Ellen Greenland receives a mysterious letter and subsequently tells her daughter that she is needed to work on a refugee program, so they have to leave their home in Auckland and move to Wellington. This strategy of displacement is used to destabilise Kirby's identity very early in the novel. The stable situation she knew is severed as mother and daughter 'drove out of Auckland and (their) old lives forever.' (Beale 1998, p.12). Later, when they finally stop at a motel for the night, Ellen informs her daughter that she is really going to work in Africa and that Kirby is to live with an uncle that she never knew existed. For Kirby her whole life has 'spun out of control in three short days. (Beale 1998, p.16). 
When Caleb Pilgrim arrives early next morning, Ellen resignedly departs for the airport, leaving her daughter in the care of Uncle Caleb. This dramatic severing of ties between daughter and mother, or self and other, results in abjection for Kirby, marked by tears, a gagging sensation, shrieking, screaming and throwing against the wall the food proffered by her Uncle Caleb and cousin Daniel. Kristeva contends that the abject marks the separation of the self from the ' $(m)$ other'. She explains, 'Abjection preserves what existed in the archaism of pre-objectal relationship, in the immemorial violence with which the body becomes separated from another body in order to be ....' (Kristeva 1982. p. 10). The abject exists on the border between the conscious and the unconscious. It is manifested in loathsome emissions expelled from the body in order to establish the 'clean and proper' self. Kristeva argues that 'all abjection is in fact recognition of want on which any being, meaning, language, or desire is founded.' (Kristeva 1982, p.5). This point, early in the narrative, presents Kirby's dislocation from her mother and results in Kirby returning to 'a stage in the preoedipal development of the subject which requires her to reorganise her boundaries with respect to inside and outside, self and other. and thus she must "expel as abject that which is not part of its "clean and proper" ego." (Coats 2000, p.291).

On their arrival at the Pilgrim home, her Uncle Caleb introduces Kirby to her Aunt Naomi and an array of cousins, as 'Esther' and regardless of her remonstrations, the Biblical name Esther is imposed on her, furthering her loss of identity. She claims piteously and to no avail. 'My name is Kirby.... I am not Esther.' (Beale 1998, p.28). An important breakthrough occurs later in the novel when Kirby/Esther's cousin, Daniel secretly speaks to her using the name 'Kirby'. Daniel's use of Kirby's 'real' name is an act of subversion against the Rule of the religious sect but for Kirby it is a glimmer of hope that her selfhood is not completely lost in the Kafkaesque world in which she has been placed.

According to Elizabeth Grosz, Lacan's 'two crucial "moments" in the social genesis of subjectivity' are the "mirror phase', which leads to the formation of the ego and the 'name-of-the-father', which identifies the entry into the symbolic order (Grosz 1990, p. 188). The result of these two significant infantile 'events' is the construction of adult sexuality, desire, and the unconscious. The unexplained upheaval in Kirby's life has caused her to revert psychically to the pre-symbolic stage. She needs to re-establish an image of herself before she can re-enter the Symbolic stage, but there are no mirrors in the Pilgrim household and, try as she might, Esther/Kirby cannot catch a glimpse of her specular image that will allow her re-entry into the symbolic order. Having been berated by her aunt for trying to find her reflection in pot lids, Esther/Kirby muses, 'If you had a mirror in the house I wouldn't have to. ... I had nightmares about looking into a mirror and having no face.'(Beale 1998, p.54). Clearly the rules of this religious sect disallow the establishment of an individual ego. This repression is reflected in their dress, manner of speaking, servitude, and denial of individual thought or creativity. Her reversion to a state of infantile solipsism is reflected in Esther/Kirby's clinging to a remnant of her clothing from the 'outside world'. In her thoughts she says, 'I took my own knickers from under my pillow. I rinsed them out every night and put them there. When they wore out I wouldn't wear any.' (Beale 1998, p.40).

Language is another important element in the psychoanalytic theories of both Lacan and Kristeva. Within the theocratic society of The Children of the Faith, there is a powerful control of language. Contraction of words is outlawed. Caleb Pilgrim has his family pray for the redemption of Esther from her unseemly ways, 'Help our beloved daughter Esther to guard her tongue so that her speech may be seemly. Help her to speak without shortening her words. Help her to be Godly.' (Beale 1998, p.34). In addition, Caleb uses prolonged prayer sessions for his family as a means of discipline and control. These also operate as a form of coercion for Kirby who realises that her own rebelliousness impacts on the whole family. Eventually Esther/Kirby learns to use language to subversively oppose her oppressive uncle. On being sent to the discipline room to learn a segment of the Bible by heart, Esther strides around the little room reciting the psalm loudly. When her racket causes her uncle to burst in on her, with ironic exuberance she says, 'The words! So beautiful! I'd never realised before, but then, I've never even opened a Bible before. Thank you!' (Beale 1998, p.43). Also evident in this segment is the idea that Esther/Kirby has rediscovered 
her own voice. She claims that in order to learn things she has to 'shout out like a town crier.' (Beale 1998, p.43). In a Lacanian sense this object voice can be seen as a means of designating subjectivity since the recognition of one's own voice produce(s) the same jubilatory effects

as those accompanying the recognition in the mirror. (Dolar 1996, p.13).

Knowledge of socio-cultural values and ideologies beyond the confines of The Children of the Faith enables Esther/ Kirby to detect the powerful patriarchal control that governs the sect. On learning that her aunt is not allowed to drive the car because she is a woman Esther/Kirby reflects, 'This family! This faith! Trust the men to grab all the fun jobs!' (Beale 1998, p.56). The patriarchal Rule in the society of The Children of the Faith can be related to the repression associated with Lacan's notion of the Name-of-the Father. For Lacan. the symbolic order is a masculine domain governed ... (by) the phallus.' (Mansfield 2000, p.48). In a sense Esther/Kirby cannot re-member herself as a subject until she is able metaphorically to grasp the phallus.

It is not until Esther/Kirby is permitted to go to the local school, beyond the confines of the religious sect, that she can begin to reconstruct her fragmented selfhood. On her arrival at the school Esther/Kirby first visits the toilet block in order to find a mirror. Contemplating her own image she thinks. 'It was strange looking at myself again. I couldn't get over how I still looked the same. If I could see a reflection of my mind, it' $d$ be so different I wouldn't recognise it. but there was the outside me-same wild hair, same big brown eyes, same everything.'(Beale 1998, p.81). In Lacan's terms she rediscovers 'the symbolic matrix in which the $/$ is precipitated in primordial form, before it is objectified in the dialectic of identification with the other: (Lacan 1977, p.2). Another step towards the re-establishment of her selfhood occurs that evening at the Pilgrim dinner table when she is berated for wearing her hair out of the sect's mandatory tight plait while at school. The dispute causes Esther/Kirby to grab the big kitchen knife (a traditional phallic symbol) and hack off her own thick plait of hair (a symbol of the repression of women of the Faith). Although ordered to her room, Esther/Kirby says of her uncle. 'I noticed a slight wobble in his voice and was fiercely glad.' (Beale 1998, p.90).
These actions enable Esther/Kirby to begin to transcend solipsism and move towards a more intersubjective identity that recognises self and other. She discovers that her pregnant Aunt Naomi is unwell and is stoically suffering her condition. Defying the patriarchal rule, by truanting from school and remaining with her sick aunt, Esther/Kirby finds herself having to obtain help for the desperately ill woman. With difficulty she manages to call an ambulance, a decisive action that ultimately saves the life of her Aunt Naomi and her premature baby. Soon after this drama Esther/Kirby begins to menstruate again. Kristeva elaborates on the notion of the cultural horror of menstruation: 'The horror of menstrual blood ... is a refusal of the expelled link between the mother and the foetus, a border ... between one existence and another that is not the same as nor yet separate from it.' (Grosz 1989, p.76). This is conveyed through the ignorance of the other girls in the religious sect, but for Esther/Kirby it is an acknowledgement of her 'corporeal link to the mother' (Grosz 1989, p.92) - to her own 'lost' mother; to her aunt's motherhood; and to her own potential motherhood. This is another important step in restoring her subjectivity, a subjectivity as it is negotiated and understood from a feminist perspective

With the help of others Esther/Kirby is released from the control of The Children of the Faith. In a rather complicated denouement, she finds her mother who is in a hospital being treated for severe depression. Esther/Kirby is oscillating between two identities: that of Esther, which has been imposed upon her through her interaction with Others of the sect; and that of Kirby, which she believes to be her self. In Lacanian terms, both are imaginary, the 'Real' being an unattainable realm beyond the Imaginary and the Symbolic. In Kristevan terms the expulsion of the (m)other through abjection allows for psychic separateness. In either sense Esther must be eliminated for Kirby to exist as a wholesome subject. As Kirby watches a television news story of The Children of the Faith moving to a new and more remote abode, she notes, 'Esther wasn't there.

Esther was dead.' (Beale 1998, p.159)

Karen Coats argues that adolescence is a 'time of reopening and rethinking questions of identity' and that in the social context adolescence is seen in terms of the way it, like abjection, breaches and challenges boundaries. 
(Coats 2000, p.292). Abjection operates as a significant element in Claire Carmichael's futuristic novel Incognito. Its adolescent protagonist, Karr Robinson, has his identity obliterated under the ruling of a corrupt data lord, who for political reasons desires Karr and his father Jonathon Robinson to be wiped off the central database of their society. A popular senior student with an excellent academic and sporting record, Karr, to his horror, finds himself an 'oblit' when checked by an identity scanner in his school. An authority tells him, 'You don't exist. ... You're an oblit.

You're not registered in the data banks. That makes you a non-person.' (Carmichael 2000, p.9). He is divested of his prefect's armband and senior jacket - a stripping of the external façade of his identity or subjectivity - and is escorted from the premises. His agency is denied and he is forced to the boundaries of his society.

Karr's prior experience of people with their identities denied is of the homeless oblits wandering the streets

people stripped of any rights to vital services.' (Carmichael 2000, p. 11). Now, he too is socially inoperative, an abject character forced to dwell on the perimeter of the dominant social order. Oblits are only able to dwell in a 'cheerless and forbidding' area known as the Tracts (Carmichael 2000, p.53). Having been rejected also from the transport system due to his invalid wristcode, Karr is forced to walk home, 'feeling cold and slightly nauseated.' (Carmichael 2000, p.27). These symptoms of abjection are exacerbated when he attempts to contact his father on a public vizaphone and finding the access to his father's office denied he 'felt as though he'd been punched hard in the stomach.' (Carmichael 2000, p.29)

Unable to enter his own apartment due to his entry code being denied, 'a bubble of rage filled Karr's throat', as he gags on his own abject state (Carmichael 2000, p.56). Later Karr discovers that his father has also been obliterated and their permitted time in their home is strictly limited. Karr sees his father arrested as an 'enemy of the state' (Carmichael 2000, p.83) and the adolescent is left alone to fend for himself on the fringes of his society. Although Karr's Uncle Leith postures as a person who will aid them through this dilemma, it gradually becomes apparent that he is a traitor, a symbol of abjection that Kristeva identi- fies as 'a terror that dissembles, a hatred that smiles.' (Kristeva 1982, p.4).

Though the mirror as metaphor or symbol is not overtly apparent in Incognito, there is electronic gadgetry that serves to affirm, or in this case negate, a person in the way Lacan suggests the mirror operates. Since Karr's implanted wristcode is no longer recognised by the electronic equipment that affirms his existence he is blocked from: communicating with others via the vizaphone; obtaining 'kredits' needed to purchase necessities like food; or gaining entry to his apartment. Attempting to secure entry to his own home Karr discovers that the equipment negates him: 'A hairline crack appeared across the screen. The lighted face of the intercom system went dark, and a thin plastic lid slid over the keys to protect them from vandalism.' (Carmichael 2000, p.56). In this sense the surveillance equipment acts as a non-reflective mirror, a darkened void that absorbs the subject allowing no reflection or affirmation of existence.

Tapping into the alienation often experienced by adolescents, Carmichael constructs a scenario in which even a 'well adjusted' young man finds his identity fragmented to the point of having no existence, thereby expressing the notion of abjection as an acknowledgement that the subject is 'in perpetual danger'. (Kristeva 1982, p.9). Karr is unable to re-member himself without the acceptance of the other and is abandoned to dwell in a limbo that constructs neither self nor other. Set in a technocratic world of the near future, Incognito conveys the desperate feelings of an adolescent focaliser who is condemned to a nightmare world in which people 'seemed not to see him.' (Carmichael 2000, p.12). As a void in the 'gaze' of the other, Karr has lost his subjectivity to the point of losing his existence.

Karr Robinson is drawn to the Tracts - a place of 'horror', marked by 'musty smells of decay and neglect' on the border of his society (Carmichael 2000, p. 103). He is met by a girl who calls him by name. This Voice of an Other is an unexpected affirmation of his existence. Brenda Cole, an agent of the underground movement known as Incognito, leads Karr deep into the heart of the Tracts, well beyond a "perimeter of vandalised, abandoned structures through to the core of the area. (which) held snug living 
units, well furnished with the latest electronic equipment.' (Carmichael 2000, p. 106). It is here that Karr is introduced to Brenda 's Aunt Jai, the (m)other figure who will aid in the re-establishment of his subjectivity. She empathasises with him saying, 'I know it's hard, Karr, to have your life fall to pieces like this.' (Carmichael 2000, p.111). Apart from the motherly warmth and security that Jai offers Karr, symbolised by mugs of hot coffee, plates of little cakes and lashings of scrambled eggs, thereby momentarily filling a facet of lack in his motherless life, she is also paradoxically in a powerful position of being a key figure in a socially subversive organisation that is fighting for the individual's right to privacy (or subjectivity) in a society that has been 'brainwashed' to believe that freedom results when 'everything is known about everybody.' (Carmichael 2000, p.51). From this transgressive position Karr is provoked to re-evaluate the limitations of his own society. Karr's subjectivity is reconstructed in dialogue with members of the subversive movement, Incognito. From this perspective he sees the rules governing his society to be corrupt since those with wealth and power certainly enjoy their privacy.

As Inge Sorenson suggests, ‘... the abject does indeed threaten to annihilate identity. At the same time, however, the abject offers the possibility of reconstructing identities. '(Sorenson 1996, p.2). Karr sublimates his abjection, in his new socio-political context, through his efforts to track down and expose the identity of the corrupt data lord in order to retrieve his identity and free his father from prison. Consequently he re-establishes his identity through dialogue with members of Incognito. In this sense the abject "is also an opportunity to re-experience the semiotic order, re-enter the mirror phase and the symbolic order and thereby recreate an identity.' (Sorenson 1996, p.4). Karr is finally able to reveal the corrupt data lord, who has instigated his and his father's obliteration.

In terms of closure of the narrative, the subversive movement. Incognito, still exists on the boundaries with only a 'fragile peace between Incognito's members and the administration. (Carmichael 2000,p. 194). Karr and Brenda Cole are reinstated as members of the society with their rebellious natures suppressed. In this sense, although the abject is sublimated, it is still hovering on the borders and is thus a constant threat to subjectivity and the dominant social order.

A romantic narrative set in medieval Japan, Across the Nightingale Floor by Lian Hearn is told predominantly from the point of view of sixteen-year-old Takeo. It documents Takeo's fragmentation, which results from the ruthless destruction of his mountain village and family by the evil warlord, Iida Sadamu. The first volume in a trilogy entitled Tales of the Otori, Across the Nightingale Floor exposes a range of connections to Lacanian and Kristevan psychoanalytic theories, both in its content and form. Takeo's fragmented selfhood is reconstructed through the 'mirror stage' and in dialogue with others. Further Lacanian elements such as 'the gaze', 'the voice' and 'the ear' also operate in the re-membering or reconstruction of self.

In the earlier section of the novel, Takeo's first-person narration alternates with a third-person narrative that follows the destiny of Kaede, a fifteen-year-old girl who is a hostage and is used as 'a pawn in struggles between the clans.' (Hearn 2002, p.42). Naturally, she becomes highly significant in Takeo's re-establishment of his selfhood later in the novel and the alternating narrative split ends, displaying a structural link with the tale continuing as solely Takeo's story. Growing up with his mother, step-father and family as a member of a pacifist clan known as the Hidden. Takeo (or Tomasu as he is known at first) is a gentle wanderer. After roaming in the surrounding countryside. Takeo returns to his village to discover the horror wreaked by Tohan warriors. In a fight for his own life against the destructive Iida Sadamu, Tomasu reveals, 'I felt as if I had split in two', thus conveying the division of the self which is to become a powerful motif in the story (Hearn 2002, p.7). In a timely act, he is rescued by Shigeru, of the Otori clan, who insists that Tomasu must 'forget that part of your life. It is over forever.' (Hearn 2002, p. 13). Shigeru renames him, Takeo. His upheaval is conveyed through his thoughts: 'I felt I had crossed over to another world.' (Hearn 2002, p.5)

In his remote mountain village of Mino there are no mirrors. Tomasu/Takeo has never been able to confront his own specular image "the symbolic matrix in which the $I$ is precipitated in primordial form, before it is objectified in the dialectic of identification with the other.' (Lacan 1977, p.2). 
Takeo is adopted as a son by Shigeru, but the protagonist's ordeal has caused him to lose his voice, leading his teacher. Ichiro, to believe he is half witted and for Takeo himself to refer to his own existence as a 'state of half-being.' (Hearn 2002, p.58). During his period of silence, however, Takeo discovers he has an acute sense of hearing and other powers which begin to manifest themselves.

A significant facet of Lacan's work is his idea of the 'Gaze' which refers to the sense that the object of our eye's look returns our gaze and that 'we constantly seek the gaze of some other ... in order to confirm our sense of presence.' (Fuery \& Mansfield 1997, p.81). However, like the mirror image, the Gaze inevitably reminds us of 'the lack' that is at the core of the symbolic order. Coupled with the Gaze is the notion of the 'Voice'. Mladen Dolar questions whether hearing and recognising one's own voice 'precedes the recognition in the mirror.' (Dolar 1996, p.13). He also suggests that the mother's voice may well be 'the first problematic connection to the Other, the immaterial tie that comes to replace the umbilical cord.' (Dolar 1996, p. 13). It is argued that the return of the gaze, having a voice, and being heard or understood by the other offers a 'confirmation of subjectivity outside our "self". ' (Fuery \& Mansfield 1997. p. 75). There are many instances in the novel where the gaze, voice, or ear. act to confirm Takeo's selfhood. Ultimately, it is his acute hearing that distinguishes Takeo. It allows him to cross Iida's nightingale floor undetected and go on to fulfil his onerous task.

Takeo's discovery of language in the form of rediscovering his own voice occurs when, after acting on his acute aural messages, he saves Lord Shigeru from an assassination attempt. This is reminiscent of the Lacanian idea of entry into the symbolic realm which is marked by loss. Takeo reflects. 'By the time the snow melted, Tomasu, the halfwild boy who roamed the mountain and read only to its animals and plants, was gone forever. I had become Takeo, quiet, outwardly gentle, an artist, somewhat bookish, in a disguise that hid the ears and eyes that missed nothing, and the heart that was learning the lessons of revenge.' (Hearn 2002, p.92). Takeo's subjectivity is not what it appears to be. His façade of being a quiet, unobtrusive artist harbours the growing attributes of a skilful warrior.
A reader can also find elements of Kristeva's work useful for interpretation of this narrative. Takeo frequently operates on borders, both physically and psychically. Growing up with the Hidden, he is part of a clan that lives remotely and peacefully in a mountainous area beyond the strongholds of the major clans. He is adopted by the Otori, but is said to really belong to the Tribe, a clan of assassins who claim him on the basis of his unusual abilities which are believed to be inherited from his natural father, himself a member of the Tribe of ninja-like assassins. He discovers that he has the ability to dissemble and uses this skill to delude his enemies. This existence on the borders of what is apparent and what is real is in itself a manifestation of abjection. There are also many instances when Takeo attempts to push away or abject things that challenge the boundaries.

Constant suspicion, intrigue, feigned persona and the apparent rather than the real permeate this novel, as do instances of blood, gore, death and decay. A nightmarish sequence is set in the township of Yamagata, a Tohan stronghold. Here Takeo discovers that some members of the Hidden clan have been torturously suspended from the castle walls to die slow, painful deaths. Taking poison capsules along with 'a short sword, thin garrottes, a pair of grapples and a rope' (Hearn 2002, p. 196) he steals silently into the night to deliver the prisoners from their torture. This act of compassion leaves him with the 'smell of blood and death' on his hands and casts him paradoxically not as a murderer but as 'an Angel' of mercy (Hearn 2002, p. 202). As Kristeva notes, 'The abject is related to perversion. ... because it neither gives up nor assumes a prohibition, a rule, or a law; but turns them aside, misleads, corrupts; uses them, takes advantage of them, the better to deny them. It kills in the name of life ...' (Kristeva 1982, p. 15). Takeo's act of compassion prefigures the later act of mercy in which he is forced to wield Shigeru's own sword to take his life. Betrayed and taken captive by the ruthless Iida, Shigeru is 'stripped of the privileges of the warrior class', (Hearn 2002, p.285) disallowed an honourable death and instead is hung from the castle walls like a criminal. Taking Jato, Shigeru's snake sword, Takeo sets out in the dead of night to release Shigeru from his painful, ignoble torture. After transporting Shigeru's broken body from the castle walls to the riverbank, Takeo is implored by his master to end his life. 
In an act of mercy, loyalty and love for his adoptive father, Takeo wields the snake sword that 'leaped and bit, and in its last service to its master, released him into the next world.' (Hearn 2002, p.298). The snake sword also operates as a phallic symbol with which Takeo takes the life of his father figure in an act of Oedipal consolidation of self.

Protecting her honour from Iida's lustful depravity, Kaede manages to kill the evil ruler using a secretly hidden needle and then a knife - also symbols of the young woman grasping the phallus in order to consolidate her own subjectivity. Finding lida's body in Kaede's chamber, Takeo feels cheated of his revenge but 'could not argue with Fate, which had dealt with him through Kaede's hands.' (Hearn 2002, p.314). As Kim Wilson argues, 'the young adult novel that is modelled on the quest motif requires the adolescent, as part of the maturation process, to come to a realization that without the significant Other they face unequivocal death.'(Wilson 2001,p.26). For Takeo, Kaede becomes that significant Other. Their stories that began as separate entities have fused in the course of the novel and both have become instrumental in the destruction of the heinous lida Saduma. Before Takeo and Kaede's parting embrace. Takeo severs Iida's head in order to deliver it as promised to Shigeru's grave, his last duty prior to giving himself up to his inevitable fate of joining the Tribe.

On his journey to Shigeru's grave, Takeo hears his name repeated over and over again as, one by one at first, and then as if with a single mind' people knelt in the dust before him bowing to the ground (Hearn 2002,pp.325-6). Members of the Otori clan and the villagers who loved Shigeru transfer their allegiance to Takeo, but at Shigeru's grave where his tears flow silently Takeo reminds himself, 'I was not his heir: I was his murderer.' (Hearn 2002, p.327). In his state of grief. Takeo finds it hard to leave the temple and surrounds of Shigeru's grave. In his dreams he is revisited by images of Shigeru's 'features streaked with blood and water.' (Hearn 2002, p.328). Takeo finally confides the contents of his disturbed mind to the priest, Makoto, who says, 'Shigeru would have been proud of you. Now you have to forgive, and be proud of, yourself.' (Hearn 2002, p. 285). Tears flow freely as Takeo abjects all that is not 'clean and proper' in himself and he says of the priest, 'Beneath his hands I felt my body come back to life. He drew me back from the abyss and made me desire to live again. Afterwards, I slept deeply, and did not dream.' (Hearn 2002, p.331). Grosz notes that Kristeva claims that 'religion functions to wrest the subject away from the abyss of abjection, to displace abjection.' (Grosz 1989, p.77).

Reading from a psychoanalytic perspective allows for an understanding of the way in which adolescent literature can tap into the unconscious and offer discourses that assist in the representation and development of subjectivity. The novels analysed here display many similar overriding themes, symbols and metaphors. Each of the three protagonists has to journey alone in search of her/his identity. It is interesting that, in these narratives, mothers are permanently or temporarily absent. As Coats has noted in relation to maternal desire in adolescent fiction, 'many authors use the dead or dying mother as a trope to represent this problem (and indeed the genre is littered with the corpses of mothers)' (Coats 2000, p.293) and thus the adolescent is forced to affirm her/his self through the dual relationship with an alternative $(\mathrm{m})$ other. Other characters assume the role of the $(\mathrm{m})$ other required in the dialectical process of establishing the self

These novels can be linked to other aspects of psy choanalytic theory such as Lacan's notion of the 'mirror stage' in the establishment of self. Phallic symbols also feature in I am NOT Esther and Across the Nightingale Floor as a means of empowering their protagonists as agents in their phallocentric societies. Additional elements such as the Gaze, the ear, and the voice offer affirmation of subjectivity as do discourses of the Other which use language symbols such as names to confirm the existence of subjects.

Additionally all three of the novels are permeated with symbols of abjection in the form of bodily emissions like blood, sweat, and tears; decaying ruins on the fringes of society; and even corpses, all of which serve as reminders of that which must be expelled or eliminated in order to discover the 'clean and proper' body of both the individual and the society. Abjection is repressed, sublimated, or displaced in order to keep it in check.

A psychoanalytic analysis of fiction suggests that subjectivity is constantly in flux and is achieved momentarily in negotiation with others. Contemporary adolescent fiction 
often reflects the " contingency, ambivalence, and instability of a threatening kind ... (that) characterize the late modern age' (Elliott 1994, p.8) and especially the instability of subjectivity in this climate. Engaging with fiction enables the reader to negotiate subjectivity both within the text and between herself/himself and the text. Thus the reader's subjectivity is also challenged, constructed and reconstructed in dialogue with fictional narrative.

\section{$\rightarrow 3: E$}

\section{REFERENCES}

Beale, Fleur (1998) I am NOT Esther. South Melbourne, Hyland House.

Carmichael, Claire (2000) Incognito. Sydney, Random House Australia.

Carroll, Lewis (1913) Alice in Wonderland. London. Ward, Lock.

Coats, Karen (2000) 'Abjection and adolescent fiction', JPCS: Journal for the Psychoanalysis of Culture \& Society 5, 2: 28-38.

Dolar, Mladen (1996) 'The object voice', in Renata Salecl and Slavoj Zizek (eds) Gaze and Voice as Love Objects. London, Duke University Press.

Elliott, Anthony (1994) Psychoanalytic Theory: An Introduction. Cambridge Massachusetts. Blackwell

Fuery, Patrick \& Mansfield, Nick (1997) Cultural Studies and the New Humanities. Melbourne. Oxford University Press.

Grosz, Elizabeth (1990) Jacques Lacan: A Feminist Introduction. London \& New York, Routledge.

Grosz, Elizabeth (1989) Sexual Subversions. Sydney, Allen \& Unwin.

Hearn, Lian (2002) Across the Nightingale Floor. Sydney, Hodder Headline.
Kristeva, Julia (1982) Powers of Horror: An Essay on Abjection, translated by Leon S. Roudiez, New York, Columbia University Press.

Kroger, Jane (1996) Identity in Adolescence: The Balance between Self and Other. London, Routledge.

Lacan, Jacques (1977) Écrits. London, Travistock.

Mansfield, Nick (2000) Subjectivity. New York, New York University Press.

McCallum, Robyn (1999) Ideologies of Identity in Adolescent Fiction. New York, Garland Publishing.

Sorensen, Inge 'Abjection in The Bone People and The Queen of The Tambourine', www.otago. ac.nz/DeepSouth/vol2no3/inge.html (accessed May 2004).

Smith, Paul (1988) Discerning the Subject. Minneapolis, University of Minnesota Press.

Wilson, Kim (2001) 'Abjection in contemporary Australian young adult fiction', Papers: Explorations into Children's Literature 11, 3: 24-31.

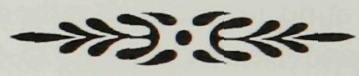

\section{BIOGRAPHICAL NOTE}

Cathy Sly is a senior high school teacher of English and Drama with the NSW Department of Education, with a Master of Arts in Children's Literature. As a member of the SCIS Reviewing Panel for over a decade, she has appraised adolescent literature and other resources for the NSW Professional Support and Curriculum Directorate and has had articles published in Scan and in Metaphor, the NSW English Teachers' Association journal. She has also composed online Book Rap resources and has been a contributor to HSC Online and HSC For Parents. 